\title{
義雪の自然観に関する研究
}

\author{
第 4 報＼cjkstart前歯の重なり（2）
}

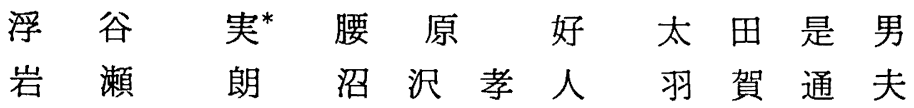

\section{A Study of the Natural Appearance in Denture.}

\section{Part 4. Overlapping of the Anterior Teeth. (2)}

M. Ukiya, Y. Koshihara, Y. Ōta, A. Iwase, T. Numazawa, M. Haga,

\section{I 緒 言}

患者は口腔疾患または異常によつて生ずる多くの障害 に対して, 咀嚼や発音機能の回復のみならず, 外貌の整 復ないし改善を望み, 殊に前歯では外観の改善に大きい 期待をよせている. この問題に対して義歯に自然感を与 えようとする試みは数多く発表されている. われわれも また臨床的立場から，この目的に向つて一連の研究を試 みてきた。

すなわち, 最初に全く正常配列と判断された嚬模型 で, 前歯の配列について基礎的な測定を行い，各歯牙の 間の相関性を調べて報告した.

次いでさらに有効に活用できるように，正常配列が仮 りに静的な美しさならばより立体的，動的な美しさを軽 度の不正配列に求めて, その配列のありさまを観察し過 去 3 回にわたつて報告して来た.

前回 (第 3 報)においては, 前歯の重なりを生ずる部位 と頻度との関係について述べたが今回は, 前歯の重なり 方の実態とその頻度について調べてみた.

\section{II 観察方法}

観祭の対象は本研究の第 3 報におけるものと同一のも のである. すなわち, 東京歯科大学所蔵の平均 21 歳を 中心とする成年男子のアルジネート印象材で印象して作 つた上下頻石高模型 751 組のうち, 全く正常な配列と判 定されるものや補緅物あるいは欠如歯のあるもの，転位

* 東京歯科大学補経学教室（指導 北村勝衙教授） Dept. of Prosthetic Dentistry, Tokyo Dental College Director: Prof. K. Kitamura
歯を有するもの, 過剩歯ならびに奇形歯を有するもの, 以上 5 頂目を除いた残りの 290 組を調查のために選ん だ.したがつて調查の対象となつたものは，上下狉前歯 のいずれかの部位に軽度の不正配列を有するものであつ て全体の $38.5 \%$ に相当する. その $5 ち$ 今回は上䫑 6 前 歯についてのみ集計した.

隣在歯相互の重なりの判定には, 前歯列の唇側観にお いて, 歯冠の一部が隣在歯によつて隠されている状態を 記録した. 左右中切歯間においては, その重なり方を, そのいずれが舌側にあるかについて調べ，中切歯と側切 歯間では，側切歯が中切歯にどう重なつているか，また 側切歯と犬歯間では，犬歯が側切歯に対して唇側あるい は舌側のどちらにあるかについて観察した。

\section{III観察結果ならびに考察}

前述の方法によつて観察した結果をまとめて次のよう な図ならびに表を作成することができた．

1）上蝒 6 前歯の各部位別によつて接触状態頻度を調 べた. (図 1)

2）中切歯と側切歯間における重なり方を百分率で現 わした（図2)

3） 中切歯の捻転の状態と, 側切歯の重なる頻度を百 分率で現わした.（図3）

4）引き続き中切歯の各捻転の型において側切歯の重 なり方，なおち 4 切歯の重なり方を図表にした。（図 $4 \sim 7$ )

5）左右中切歯上側切歯の配列を一括して表にまとめ た. (表 1) 


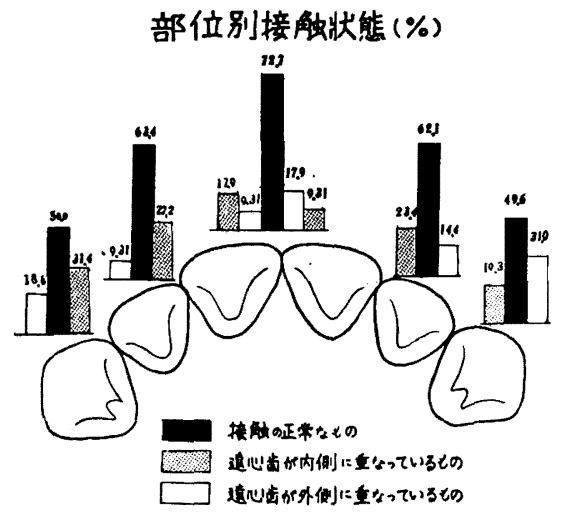

図 1

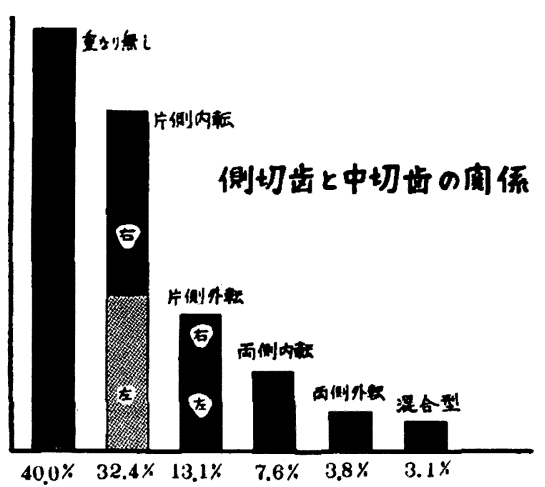

図 2

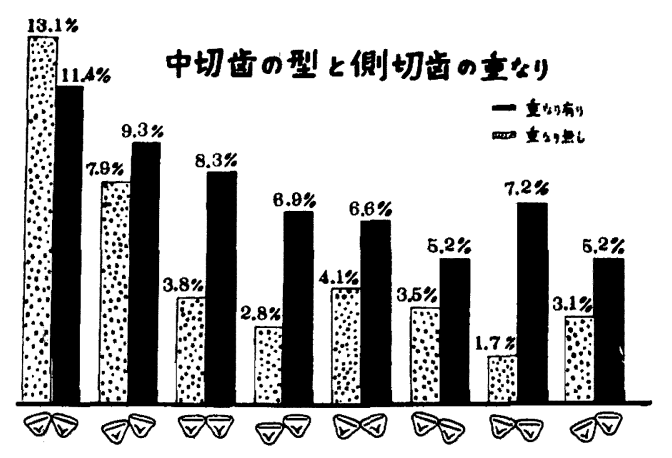

図 3

以上の資料から判じて次のよらなことが考えられる.

1. 上額 6 前歯各歯間における接触状態を観ると, 両 中切歯間においては，右側が舌側に重なつている場合が 290 例中 $17.9 \%$ ，唇側に重なつている場合が $9.3 \%$ ， この両者の比は約 $2: 1$ である. 中切歯側切歯間では, 左右側ともに側切歯が舌側に重なつているものが多い.

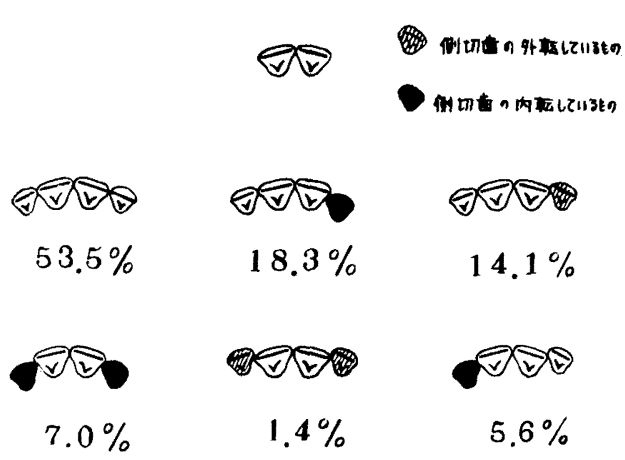

図 4 外枟 型

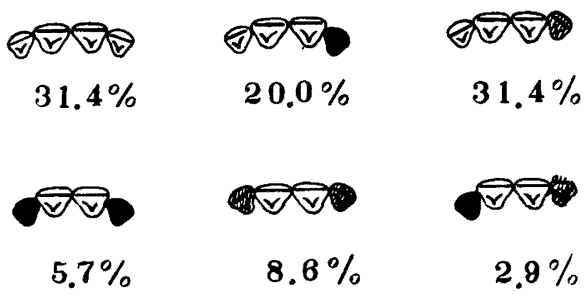

図 5 直線 型
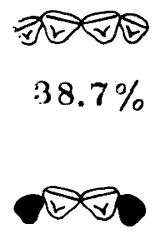

$16.1 \%$

\section{$\sqrt{-0}$}

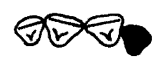

$38.7 \%$

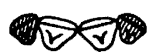

o

\section{बत्O}

$6.5 \%$

図6内枟 型

すなわち左側では，側切歯が舌側に重なつている場合が $23.4 \%$, 唇側に重なつている場合が $14.4 \%$ ，この両

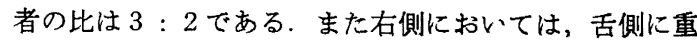
なつている場合が $27.2 \%$ ，唇側に 重なつている場合が $9.3 \%$ ここの両者の比は約 $3: 1$ である. したがつて右 側の方が舌側に重なる頻度がわずかに大きい． 
$\theta$

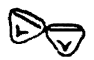

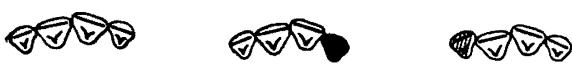

तथ तथ

$46.0 \% \quad 24.0 \% \quad 10.0 \%$

$19.2 \%$

$65.4 \%$

$7.7 \%$

장
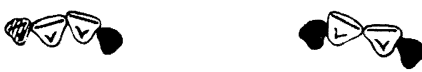

DD?

$\rightarrow=$

$4.0 \%$

$8.0 \%$

$8.0 \%$

$7.7 \%$

0

0

図 7 a

図 $7 d$

$\approx 0$

$\nabla$

बत्र

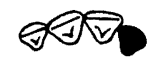

बृत्

$37.5 \%$

$41.7 \%$

$8.3 \%$

तथि

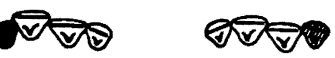

$17.9 \%$

$28.6 \%$

$46.4 \%$

ब2)

$4.2 \%$

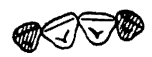

(4)

$8.3 \%$

0

図 $7 \mathrm{e}$

図 7 混合 型

$3.6 \%$

0

図 $7 b$

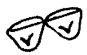

क्षि

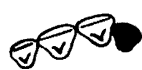

00

$40.0 \%$

$40.0 \%$

$4.0 \%$
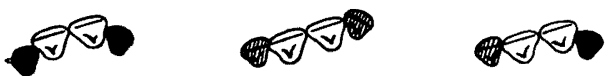

$16.0 \%$

0

0

図 $7 \mathrm{c}$

表 1 中切歯と側切歯のまとめ

\begin{tabular}{|c|c|c|c|c|c|c|c|c|c|}
\hline 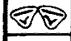 & 24 & 3 & 4 & 2 & 3 & 3 & 0 & 2 & 41 \\
\hline$\theta$ & 14 & 4 & 2 & 4 & 1 & 2 & 1 & 2 & 30 \\
\hline$\Rightarrow$ & 4 & 0 & 4 & 2 & 0 & 2 & 1 & 2 & 15 \\
\hline & 19 & 6 & 2 & 1 & 2 & 0 & 3 & 2 & 35 \\
\hline$\nabla \nabla$ & 11 & 3 & 4 & 10 & 1 & 2 & 3 & 1 & 35 \\
\hline$\vec{\nabla}$ & 3 & 2 & 5 & 1 & 1 & 0 & 0 & 0 & 12 \\
\hline$\nabla \theta$ & 5 & 4 & 2 & 1 & 2 & 1 & 1 & 0 & 16 \\
\hline 8 & 4 & 2 & 4 & 0 & 0 & 1 & 0 & 0 & 11 \\
\hline$B(3)$ & 8 & 3 & 3 & 1 & 1 & 4 & 0 & 0 & 20 \\
\hline 8 & 3 & 2 & 4 & 0 & 1 & 0 & 0 & 0 & 10 \\
\hline (4) & 7 & 1 & 3 & 0 & 0 & 4 & 0 & 0 & 15 \\
\hline$\Delta$ & 4 & 5 & 0 & 0 & 0 & 0 & 0 & 0 & 9 \\
\hline$\approx(3)$ & 1 & 2 & 10 & 2 & 0 & 2 & 0 & 0 & 17 \\
\hline 40 & 7 & 1 & 1 & 1 & 0 & 0 & 1 & 0 & 11 \\
\hline $\mathbb{E}$ & 2 & 4 & 4 & 1 & 0 & 1 & 1 & 0 & 13 \\
\hline 言 & 116 & 42 & 52 & 26 & 12 & 22 & 11 & 9 & 290 \\
\hline
\end{tabular}


側切歯犬歯間は右側では 犬歯が舌側に 重なる 場合が 31 \%，唇側に重なつている場合が $18.6 \%$ である．左側に おいては右側と全く逆の傾向を示し，犬歯が唇側に重な つている場合が多く 31 \% ，舌側にある場合が $19 \%$ \% , この両者の比は約 $3: 2$ である.（図 1)

2. 先に左右中切歯, 側切歯間の個々について述べた が, 次にこの 4 前歯の組合せについて調べたのが，図 2 である.

1）中切歯に対して側切歯が重ならない場合が $40 \%$, 重つている場合が $60 \%$ ，重つているものは，290例 中 5 分の 3 を占めている.

2） 4 前歯のらち 中切歯と 側切歯間が， a) 片側のみ 重なつている場合が最も多く $45.5 \%$ ，b）左右対称的に 重なつている場合がこれに次ぎ $11.4 \%$ ，最も少ないの は，c）左右に拉いて逆の重なり方をしている場合で 3.1 \%である.そして a)b) において，敌側に重なつている 場合が唇側に重なつている場合の約 2 倍である，その中 でも，側切歯が片側のみ舌側に重なつている場合が最も 多く, 重なりのみられるもののらちで $53 \%$ で約半数を 占めている.この傾向は左右ともにほぼ同じ割合で現わ れている.それに対して片側のみ唇側に重なつている場 合は $21.8 \%$ に過ぎない. 1 側のみ唇側に重なる場合は, 左側が右側に較べて 2 倍の值を示している. 側切歯が中 切歯に対して左右両側とも重なつている場合は，両側と も舌側に重なっている場合が $12.7 \%$, 唇側に 重なって いる場合が $6.3 \%$ で，その両者の比は $2 ： 1$ である。 ま た左右が，たがいに逆に重なる場合，すなわち 1 側が唇 側に，反対側が舌側に重なっているものが $5.1 \%$ \%゙あつ た.

3. 左右中切歯の捻転の程度と, それに対する側切歯 の重なり方と，その頻度を図 3 で示した，すなわち，中 切歯の外転型 ( $\wedge$ 型)においてのみ，わずかに重なりのな い場合の方が多いが, 直線型から, 内転型 $(\vee$ 型) に向5 にしたがつて重なりの現われる頻度が多くなっている。

次に中切歯の各々捻転の型における側切歯の重なり方 については,

1）外転型 ( $\wedge$ 型)の場合は, 先に述べたように, わず かではあつたが重なりのない場合が多く，そしてその傾 向は第 2 図の傾向とほぼ同じである。すなわち片側側 切歯が, 重つている場合が多く，その中で，舌側に重な つている場合が $18.3 \%$ ，唇側に重なつている場合が $14.1 \%$ である. 両側に重なりの現われる場合は，側切 歯が舌側に重なる場合が $7.0 \%$ で最も多く，唇側に重な つている場合は $1.4 \%$ で極めて少い(図 4 ).
2）中切歯の直線型においてもやはり片側にのみ重な りのみられる場合が多い：しかし外転型の場合と異る点 は，唇側に重なる場合が $31.4 \%$ ，舌側に重なる 場合が $20 \%$ で，その比は約 $3: 2$ で側切歯が唇側に 重なる場 合の方が多いといらことである. 両側に現われている場 合も同じ傾向にある(図 5 ).

3） 内転型 $(\vee$ 型)においては, 側切歯の片側が舌側に 重なつている場合がやはり非常に多く $38.7 \%$ ，片側が 唇側に重なつている場合 $6.5 \%$ で, 6 倍にも達している. また両側側切歯が舌側に重なつている場合が $5.7 \%$, 片 側が外側に重なつている場合より多く，2.5 倍の值を示 している. また両側切歯が唇側に重なつている場合は, 全くなかつた. 寸なわち中切蒾が内転型 $(\vee$ 型) の場合, 側切歯が唇側に重なることは非常に少いといらことがで きる(図 6 ).

人工歯配列にこれらの事象を活用しょうとする場合： 中切歯を内転型 $(V$ 型)にしょうと定めれば, 側切歯は舌 側に重なりを与えると，自然観を表現することができ る. また個性的な配列にしよらとすれば側切歯を外側に 重㸚ることによつて目的を達し得るように考える.

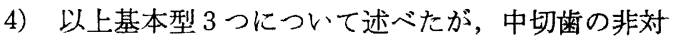
称的な配列である混合型における重なり方は, ほぼ上記 3 型の組合せであつて，またその移行的傾向を示してい る.たとえば図 $7 \mathrm{c}$ は片側の中切歯が外転型をとり, 他 側の中切歯が内転型を示す混合型では, 中切歯に続く側 切歯の重なり方は基本型の組合せにおける発現頻度の組 合せにほぽ一致している．図 $7 \mathrm{~d}, 7 \mathrm{e}$ ともにその傾向 を示している．このことは人工歯を配列するに際して簡 単にして要を得た一つの道しるべとなることと考える.

\section{IV総括ならびに結論}

前回において上顎 6 前歯間に重なりの生ずる部位と頻 度について述べたが，今回は引続き重なり方の寒態につ いて観察した。 その結果, 次のようなことが明らかにな つた.

1. 上顎 6 前齿各歯間の重なり方の傾向をみると左右 中切歯では左側が唇側に重なる場合が多く, 左側側切歯 と犬歯間に㧍いて犬歯が唇側に重なる場合が多い，

他の 3 つの部位, いいかえると右側 3 前㐘相互間と左 側中切歯, 側切歯間においては遠心側の歯が近心側の歯 の舌側に重なる場合が多い。

2. 中切歯と側切歯との関係についで特にみると, 両 歯牙が重なつているものが 5 分の 3 を占め, その中で片 側が重なつている場合が最も多く（a）, 次が左右対称的 
に重なるもので(b)，最も少ないのは左右それぞれ逆に 重なる場合である (c). そして (a) (b) にお扔いて 側切歯 が，内側に重なる場合が唇側に重なる場合の約 2 倍であ る.

3. 左右中切歯の捻転と, それに続く側切歯の重なり 方を検討すると, 中切歯が外転型 $(\wedge$ 型 $)$ から直線型, 次 いで内転型 ( V型)へと移行するにしたがつて重なりの現 われる頻度が多くなつている.すなわち

1) 外転型 ( $\wedge$ 型) の場合は 71 例中の 約半数が 正常で 残りの約 3 分の 1 は片側側切歯が中切歯の舌側に, 次い で片側側切歯が逆に唇側に重なるものが多い.

これは外転型が正常型に近いためと考える.

2）直線型では二者,すなわち外転型と内転型の中間 の傾向を示し，中切歯と側切歯間が正常な関係にあるも のと片側側切歯が 唇側に重なつているものとが $31.4 \%$ でほぼ同数である.片側側切歯が舌側に重なつているも のが $20 \%$ である.

3）内転型 $(\vee$ 型)では，中切歯と側切歯が正常な配列 にあるものと, 片側側切歯が舌側に重なつているものと
がほぼ同数となって $38.7 \%$ で最も多く，両側側切歯と も舌側に重なつているものがそれに次ぎ $16.1 \%$ ，片側 側切歯が唇側に重なつているものは $6.5 \%$ にすぎなかつ た.なお両側側切歯がともに唇側に重なる場合と片側が 唇側に反対側が舌側に重なる場合は 290 例中には皆無で あつた。

以上今回は側切歯を中心にまとめたが，次回はさらに 犬歯を加えて報告する予定である.

稿を終るにあたり終始御㸸篤なる御指尊並びに御校閲 を戴いた北村勝衙教授に㳭甚なる謝意を表します。

\section{参考文献}

1）慗庭他：日本補経歯科学会嚾誌， $2,1,135,1958$.

2）唫庭他：日本補緅歯科学会雑誌，2,2, 141, 1958 .

3）整庭他：日本補燓菌科学会雑誌，2,2, 145, 1958.

4）郘庭他：日本補緅菌科学会雑誌， $3,1,28,1959$.

5）㢣庭他：日本補緅歯科学会雑誌，3,2, 175, 1959.

6）郘庭他：日本補経画科学会雑誌， $3,2,179,1959$.

7) 羽賀他：日本補緅菌科学会雑誌，4,2, 95, 1960.

8）羽賀他：日本補緅歯科学会雑誌， $5,1,58,1961$.

9) 羽賀他：日本補刢歯科学会雑誌，6,1, 53, 1962. 